\title{
PENGARUH PRODUK YANG BERWAWASAN HIJAU TERHADAP MINAT BELI PRODUK AIR MINUM DALAM KEMASAN MEREK ADES
}

\author{
Devi Eprilia Ristanti \\ Department of Management FEB UMM \\ E-mail: eristanti.devi@gmail.com
}

\begin{abstract}
The research purpose's is to analyze the effect of green-minded products on purchase intention. This research is survey. The research used a questionnaire for collecting data. The result indicated that green-minded product positively influencing purchase intention.
\end{abstract}

Keywords: Green-minded Product, Purchase Interest, and ADES

\section{PENDAHULUAN}

Permasalahan lingkungan dan kesehatan yang secara langsung dan tidak langsung diakibatkan oleh aktivitas manusia, baik di bidang ilmu pengetahuan dan teknologi, pertanian, ekonomi dan bisnis, telah menjadi issue sentral di semua kalangan. Kepedulian dan kesadaran akan lingkungan dan kesehatan, telah merubah cara pandang dan pola hidup dari manusia dan para pelaku usaha. Hal ini ditunjuk kan pada perubahan pola pendekatan bisnis yang mulai mengarahkan usaha dengan pendekatan aktivitas bisnis berbasis kelestarian lingkungan.

Pemanasan global (global warming) yang terjadi membuat masyarakat semakin hati-hati menggunakan berbagai produk yang dikhawatirkan dapat menambah level pemanasan global pada level yang membahayakan umat manusia. Peningkatan ini dicetuskan oleh adanya kekhawatiran besar kemungkinan terjadinya bencana lingkungan hidup yang mengancam, bukanhanya kesehatan, namun bahkan sampai pada kelangsungan hidup manusia dan keturunannya.

$$
\text { Keadaan bumi dapat }
$$

digambarkan dari penjelasan tim ilmuwan PBB yang tergabung dalam Panel Antar Pemerintah tentang perubahan iklim yang mengatakan "manusia adalah penyebab utama pemasan global". Dalam laporan tahun 2013 tentang perubahan iklim yang dibuat oleh IPCC (Intergovernmental Panel on Climate Change), menggambarkan sebuah fenomena dari pemanasan global yang terus meningkat sejak tahun 1950-an dan menyakini bahwa 95\% penyebab pemanasan global adalah ulah manusia. "Kajian ilmiah kami menunjukkan bahwa atmosfir semakin panas jumlah salju es berkurang dan permukaan air laut bisa meningkat hingga $82 \mathrm{~cm}$ sebelum akhir abad ini" kata Qin Dahe, salah satu anggota IPCC yang menyusun laporan. 
Kesadaran masyarakat yang meningkat tentang pentingnya menjaga kelestarian lingkungan hidup membuat banyak produsen dari berbagai macam produk mulai beralih menggunakan bahan-bahan yang tidak merusak lingkungan atau istilah lainnya bahan yang ramah lingkungan. Bahan-bahan yang dimaksud tidak hanya bahan baku produk melainkan juga menyangkut material lainnya seperti kemasan produk, pelabelan, karton pembungkus dan lain sebagainya.

Konsep pemasaran produk yang menggunakan bahan-bahan yang tidak merusak lingkungan hidup sekarang ini dikenal dengan nama pemasaran hijau. Langkah-langkah pemasaran hijau yang sudah dilakukan oleh banyak produsen pada dasarnya direspon secara positif oleh konsumen. Mathur (2000:194) mengatakan." Consumers tend to respond more favorably to firms with environmentally conscious images". Namun respon positif bukan berarti konsumen seratus persen mengatakan"ya" pada produk hijau dalam arti apa bila harga jual produk hijau lebih mahal dari produk nonhijau bisa saja konsumen lebih memilih produk non-hijau. Perhatian terhadap isu-isu lingkungan ini ditandai dengan maraknya para pelaku bisnis dalam menerapkan standar internasional atau lebih dikenal dengan ISO-14000 yang merupakan system manajemen lingkungan yang dapat memberikan jaminan (bukti) kepada produsen dan konsumen bahwa dengan menerapkan system tersebut produk yang dihasilkan/dikonsumsi baik limbah, produk bekas pakai, ataupun layanannya sudah melalui suatu proses yang memperhatikan kaidahkaidah atau upaya-upaya pengelolaan lingkungan.

International Organization for Standardization (ISO) mengembangkan suatu seri standar internasional untuk ekolabel (ISO 14020- ISO14024).' Ekolabel (eco-labelling) diartikan sebagai kegiatan pemberian label yang berupa simbol, atribut atau bentuk lain terhadap suatu produk dan jasa. Label ini akan memberikan jaminan kepada konsumen bahwa produk/jasa yang dikonsumsi tersebut sudah melalui proses yang memperhatikan kaidahkaidah pengelolaan lingkungan.

ADES merupakan salah satu produk minuman yang sangat peka terhadap isu global warming yang terjadi saat ini, sehingga dapat menarik perhatian banyak khalayak umum. Pada umumnya promosi yang dilakukan air minum kemasan merek lain, lebih membahas tentang aspek kesehatan dan keunggulan produk seperti proses produksi air dan sebagainya. Produk minuman ADES mempunyai keunggulan yaitu pelopor iklan yang membahas tentang aspek lingkungan, hal ini yang membedakan dengan iklan air minum kemasan merek lainnya. "Pengembangan produk Ades ini mengembangkan komitmen kami yaitu live positively komitmen berlandaskan keberlanjutan dan tanggungjawab kepada lingkungan" jelas Ratri Wuryandari manager Coca Cola Indonesia.

Green marketing mempunyai peranan yang penting dalam meningkatkan citra khususnya persepsi tentang Green Brand karena iklan hijau tersebut mengkhususkan untuk merek yang mempunyai tujuan peduli pada lingkungan, dan tujuan 
akhir dari iklanya itu untuk menciptakan keputusan pembelian. Green brand menurut Keller et al., dalam Mourad dan Ahmed (2012:522) merupakan persepsi terhadap citra merek hijau yang terasosiasi di benak konsumen yang terkait dengan penawaran produk atau jasa yang berkaitan dengan lingkungan. Persepsi tentang green brand merupakan salah satu strategi yang dilakukan oleh perusahaan bahwa merek tersebut semata-mata tidak melihat aspek keuntungan tetapi juga melihat aspek lingkungan.

Aspek-aspek yang meliputi dalam persepi green brand menurut Mourad dan Ahmed (2012:523) meliputi merek yang berkomitmen terhadap aksi peduli terhadap lingkungan, konsumen merasa puas tentang tindakan yang dilakukan oleh merek yang bertanggungjawab terhadap lingkungan, selain itu konsumen percaya terhadap tindakan yang dilakukan merek tersebut terhadap aksinya untuk lingkungan dan consumen merasa sadar memilih merek karena tindakan yang positif terhadap lingkungan. Rumusan masalah dalam penelitian ini yaitu Apakah produk yang berwawasan hijau berpengaruh terhadap minat beli konsumen air minum dalam kemasan merek Ades?

Tinjauan dari r peneliti
terdahulu yang $\begin{array}{r}\text { dijadikan } \\ \text { pertimbangan adalah penelitian }\end{array}$
tentang Green Marketing dan
pengaruhnya terhadap keputusan
pembelian melalui minat membeli
produk hijau. Allen A.Ch. Manongko
Green Marketing dan Pengaruhnya
Terhadap Keputusan Pembelian
Melalui Minat Beli Produk Organik.
Hasil penelitian ini menunjukkan

bahwa: green marketing berpengaruh secara langsung dan signifikan terhadap minat membeli; green marketing tidak berpengaruh secara langsung dan signifikan terhadap keputusan pembelian; minat membeli berpengaruh secara langsung dan signifikan terhadap keputusan pembelian; green marketing berpengaruh secara tidak langsung dan signifikan terhadap keputusan pembelian dengan minat membeli sebagai variabel interviening.

\section{TINJAUAN PUSTAKA}

Pemasaran hijau telah diterima secara luas diantara beberapa perusahaan sebagai sebuah strategi bersaing yang pantas. Istilah "green" atau hijau sering dipertukarkan dengan kata "pro-environmental" atau pro lingkungan. Banyak perusahaan berkomitmen untuk melakukan pemasaran hijau dalam komunikasi pemasaran mereka. Tujuannya adalah untuk meraih pangsa pasar yang lebih luas pasar yang terus tumbuh dari konsumen yang peduli lingkungan.

Salah satu permasalahan yang ada sekarang adalah bahwa produk kantong sampah plastik, akan segera mengalami penurunan penjualan karena para pesaing telah mempromosikan merek mereka sebagai produk yang dapat diuraikan oleh tanah (degradable). Dalam waktu bersamaan banyak pemasar yang mulai menanggapi kepedulian konsumen tersebut. Survei untuk mengetahui opini publik menunjukkan bahwa semakin banyak konsumen yang peduli dengan apa yang terjadi pada lingkungannya, dan menuntut perusahaan untuk mencipyakan lingkungan yang lebih 
bersih dan lebih nyaman dan konsumen bersedia membayar lebih untuk produk yang tidak merusak lingkungan (Terence A. Shimp: 2000, h.69).

Pemasaran menurut Laksana (2008:4) adalah segala kegiatan yang menawarkan suatu produk untuk memenuhi kebutuhan dan keinginan konsumen. Menurut Banarje dalam Ozkocak (2011:2) Green marketing adalah iklan yang mempunyai kriteria, secara eksplisit maupun implisit mempromosikan tentang lingkungan biofisik, mempromosikan gaya hidup ramah lingkungan dengan produk maupun jasa yang ramah lingkungan, dan mempresentasikan perusahaan yang peduli pada lingkungan. Dari beberapa pendapat tokoh-tokoh tentang Green marketing dapat disimpulkan bahwa Green marketing merupakan salah satu strategi pemasaran yang mengkaitkan antara iklan dengan isu-isu lingkungan sehingga konsumen bisa membedakan dengan iklan-iklan produk lainya.

Menurut Keller et al., dalam Mourad dan Ahmed (2012:522) Green Brand merupakan citra merek hijau yang mendapat persepsi dan asosiasi di benak konsumen yang terkait dengan penawaran produk atau jasa. Menurut Cretu et al., dalam Mourad dan Ahmed (2012:523) Green Brand tersebut adalah persepsi dan asosiasi dalam ingatan konsumen, bahwa merek tersebut komitmen dan berkepentingan untuk lingkungan. Berdasarkan definisi mengenai green brand dapat disimpulkan bahwa Green Brand merupakan merek hijau yang mendapat persepsi dari konsumen tentang produk atau jasa yang mengacu pada lingkungan. Green Brand juga dapat menjadi merek pembeda dengan produk lainnya yang tidak mengkaitkan dengan kelestarian alam. Green Brand atau merek hijau juga merupakan atribut produk yang diselaraskan dengan harmonisasi alam.

Schiffman dan Kanuk (2004:25), menjelaskan bahwa pengaruh eksternal, kesadaran akan kebutuhan, pengenalan produk dan evaluasi alternatif adalah hal yang dapat menimbulkan minat beli konsumen. Pengaruh eksternal ini terdiri dari usaha pemasaran dan faktor sosial budaya menurut Simamora (2002:131) minat adalah sesuatu yang pribadi dan berhubungan dengan sikap, individu yang berminat terhadap suatu obyek akan mempunyai kekuatan atau dorongan untuk melakukan serangkaian tingkah laku untuk mendekati atau mendapatkan objek tersebut.

Menurut Kotler, Bowen dan Makens (1999:156) minat beli timbul setelah adanya proses evaluasi alternatif dan di dalam proses evaluasi, seseorang akan membuat suatu rangkaian pilihan mengenai produk yang hendak dibeli atas dasar merek maupun minat. Dari beberapa pendapat tokoh tentang minat beli dapat disimpulkan bahwa minat beli timbul setelah adanya kesadaran akan kebutuhan dan proses eavaluasi alternatif dalam membuat suatu rangkaian produk yang akan dibeli. Swastha dan Irawan (2001) mengemukakan faktor-faktor yang mempengaruhi minat membeli berhubungan dengan perasaan dan emosi, bila seseorang merasa senang dan puas dalam membeli barang atau 
jasa maka hal itu akan memperkuat minat membeli, ketidakpuasan biasanya menghilangkan minat.

Gambaran hubungan antar variabel dalam penelitian ini secara substansial, yang menjelaskan alur hubungan antar variabel produk yang berwawasan hijau dan pengaruhnya terhadap minat membeli produk produk air minum dalam kemasan Ades di Kecamatan Gondanglegi Kabupaten Malang. Berdasarkan kerangka konsep, yang telah diuraikan diatas dan untuk menjawab permasalahan penelitian ini, maka kerangka konsep tersebut dijabarkan dalam kerangka alur hubungan antar variabel seperti yang tampak pada gambar berikut: daftar pertanyaan (kuesioner) kepada responden mengenai pengaruh produk yang berwawasan hijau terhadap minat beli.

Populasi yaitu masyarakat Kecamatan Gondanglegi Kabupaten Malang. Sampel adalah sebagian dari jumlah dan karakteristik yang dimiliki oleh populasi tersebut, dalam hal ini sampel adalah masyarakat Kecamatan Gondanglegi Kabupaten Malang yang pernah melakukan pembelian produk air minum dalam kemasan Ades. Teknik pengambilan sampel yang digunakan dalam penelitian ini yaitu menggunakan teknik accidental sampling. Dalam penelitian ini teknik pengumpulan data dengan menggunakan kuesioner

Gambar 1. Model Kerangka Hipotesis

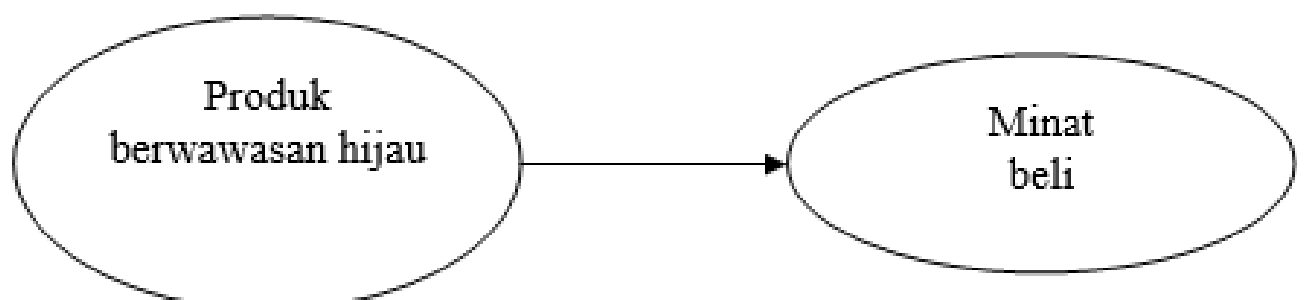

\section{METODE PENELITIAN}

Lokasi penelitian yang digunakan dalam penelitian ini yaitu di Kecamatan Gondanglegi Kabupaten Malang. Jenis penelitian yang lakukan ini adalah penelitian survey, dimana peneliti melakukan observasi dalam pengumpulan data, peneliti hanya mencatat data seperti apa adanya, menganalisis dan menafsirkan data tersebut. Data yang digunakan dalam penelitian ini yaitu menggunakan data primer, menurut Santoso dan Tjiptono (2000:59) data primer adalah data yang dikumpulkan dan diolah sendiri oleh suatu organisasi atau perorangan langsung dari objeknya. Dalam hal ini data primer tersebut berupa hasil pengisian (angket). Teknik angket merupakan suatu pengumpulan data dengan memberikan atau menyebarkan daftar pertanyaan/pernyataan kepada responden yaitu mengenai pengaruh produk yang berwawasan hijau terhadap minat beli. Dalam penelitian ini, digunakan daftar pertanyaan bersifat tertutup, di mana alternatif jawaban telah disediakan. Teknik analisis data yaitu menggunakan 1) Rentang skala digunakan untuk menggambarkan tanggapan responden atas kuesioner mengenai variabel produk dan minat beli 2) Analisis Regresi Logistik, merupakan salah satu jenis analisis regresi yang bisa digunakan untuk memprediksi 
(estimasi atau eksplanasi) permasalahan hubungan dan pengaruh. Hubungan pengaruh dalam logistik regresi merupakan hubungan pengaruh yang mana variabel terikatnya (dependent variable) variabel berskala nominal, binary juga dapat digunakan untuk melihat hubungan memprediksi besarnya probabilitas suatu peristiwa yang dipengaruhi satu atau lebih variabel.

\section{HASIL PENELITIAN DAN PEMBAHASAN}

Berdasarkan hasil analisis regresi logistik yang telah dilakukan dengan menggunakan program SPSS (Statistical Product and Service Solutions) release 13,00 for windows maka didapatkan hasil perhitungan seperti pada tabel 1 .

Berdasarkan hasil analisis regresi logistik pada tabel 1 , maka dapat dibentuk suatu persamaan regresi logistik yaitu sebagai berikut: $Z=-9,603+0,909 X$

Dari persamaan $\mathrm{Z}$ tersebut dapat ditentukan besarnya probabilitas responden, berdasarkan hasil analisis dengan menggunakan SPSS (Statistical Product and Service Solutions) release 13,00 maka dapat diketahui probabilitas responden secara keseluruhan. Probabilitas responden untuk responden pertama diperoleh angka sebesar 0,78655 karena nilai probabilitasnya $>0,5$ maka responden ini masuk dalam kategori responden mengkonsumsi produk air minum dalam kemasan merek Ades (memilih jawaban 1). Jika probabilitasnya $<0,5$ maka responden tersebut dikelompokkan pada responden tidak mengkonsumsi produk air minum dalam kemasan merek Ades, demikian juga jika dilakukan sampai pada responden yang terakhir. Nilai probabilitas tersebut ditentukan dari nilai kemungkinan seorang responden atas minat beli konsumen.

Berdasarkan tabel 2 dapat dilihat bahwa dari 100 responden yaitu masyarakat Kecamatan Gondanglegi Kabupaten Malang terdapat 20 responden yang tidak berminat mengkonsumsi produk air minum dalam kemasan merek Ades dan hasil observasi dengan analisis regresi logistik menunjukkan terdapat 18 responden yang masuk dalam pengelompokan responden yang berminat mengkonsumsi produk air minum dalam kemasan merek Ades dan sebesar 38 responden dalam kelompok tidak berminat mengkonsumsi produk air minum dalam kemasan merek Ades atau dengan kata lain sebesar 52,6\% dari 38 responden dapat dikelompokkan secara tepat dalam model

Observasi terhadap 62 responden terdapat 54 responden yang berminat mengkonsumsi produk air minum dalam kemasan merek Ades, sedangkan 8 responden masuk dalam pengelompokan responden yang tidak berminat, dengan kata lain sebesar 87,1\% dari 62 responden dapat dikelompokkan secara tepat oleh model. Berdasarkan hasil analisis tersebut maka secara umum model yang diperoleh dapat diandalkan dalam memprediksi para responden sebesar $74 \%$ karena dapat menentukan minat beli masyarakat terhadap air minum dalam kemasan merek Ades. 
Tabel 1. Koefisien Regresi Logistik

\begin{tabular}{|c|c|c|c|c|}
\hline Variabel & Koefisien & Standar Error & Wald & Sig. \\
\hline Produk & 0,909 & 0,238 & 14,644 & 0,000 \\
\hline Constant & $-9,603$ & 2,620 & 13,431 & 0,000 \\
\hline \multicolumn{5}{|c|}{ Tabel 2. Classsification Table } \\
\hline \multicolumn{5}{|c|}{ Predicted } \\
\hline Observed & $\begin{array}{l}\text { Tidak berminat } \\
\text { mengkonsumsi } \\
(0)\end{array}$ & $\begin{array}{l}\text { Berminat } \\
\text { engkonsumsi } \\
\text { (1) }\end{array}$ & Total & $\%$ \\
\hline 0 & 20 & 18 & 38 & 52,6 \\
\hline 1 & 8 & 54 & $\begin{array}{c}62 \\
100\end{array}$ & $\begin{array}{c}87,1 \\
74,0 \%\end{array}$ \\
\hline
\end{tabular}

Berdasarkan hasil analisis ini dapat diketahui dari nilai signifikansi yang lebih kecil dari Alpha (5\%). Berdasarkan hasil tersebut dapat dikatakan bahwa variabel produk yang berwawasan hijau mempunyai pengaruh yang signifikan terhadap minat beli konsumen air minum dalam kemasan merek Ades. Besarnya pengaruh dapat diketahui dari besarnya nilai $R$-Square Cox \& Snell pada tabel model summary. Dari hasil perhitungan diperoleh nilai $\mathrm{R}^{2}=$ 0,190 (19\%), artinya variabel produk dan promosi berpengaruh terhadap minat beli sebesar 19\%, sedangkan sisanya sebesar $81 \%$ dipengaruhi oleh variabel-variabel lain yang tidak dimasukkan dalam model persamaan.

Pada pengujian hipotesis dinyatakan bahwa diduga produk yang berwawasan hijau berpengaruh terhadap minat beli produk Ades. Untuk menguji hipotesis ini maka digunakan uji signifikansi. Adapun hasil pengujian hipotesis pertama dapat dilihat pada tabel 3 .

Berdasarkan tabel 3 maka dapat diketahui bahwa: Nilai signifikansi untuk variabel produk yaitu sebesar $0,000<$ nilai Alpha $(0,05)$, maka dapat menolak $\mathrm{H}_{0}$. Dengan demikian dapat dikatakan bahwa terdapat pengaruh signifikan antara produk yang berwawasan hijau terhadap minat beli produk air minum dalam kemasan merek Ades. Dari hasil tersebut dapat dikatakan bahwa hipotesis yang diajukan terbukti diterima, yang menyatakan bahwa produk yang berwawasan hijau berpengaruh signifikan terhadap minat beli produk air minum dalam kemasan merek Ades.

Berdasarkan hasil penelitian dan pembahasan maka dapat ditarik kesimpulan bahwa produk yang berwawasan hijau berpengaruh terhadap minat beli produk air minum dalam kemasan merek Ades.

Tabel 3. Hasil Uji Hipotesis

\begin{tabular}{lccc}
\hline Variabel & $\alpha$ (Alpha) & Sig. & Keterangan \\
\hline Produk & 0,05 & 0,000 & Tolak $\mathrm{H}_{\mathrm{o}}$ \\
\hline
\end{tabular}


Selain itu kegiatan promosi yang dilakukan dapat memberikan dorongan konsumen untuk melakukan pembelian produk sehingga mendukung upaya perusahaan dalam meningkatkan penjualan produk. Perusahaan harus berupaya secara maksimal dalam upaya mempengaruhi minat beli konsumen yaitu dengan menawarkan produk yang benar-benar mampu memberikan jaminan kepuasan setelah mengkonsumsi produk.

\section{DAFTAR PUSTAKA}

Basu Swastha dan Irawan. 2001. Manajemen Pemasaran Modern. Edisi Kedua. Cetakan Kedua. Yogyakarta: Liberty.

Bilson, Simamora. 2002. Membongkar Kotak Hitam Konsumen. Jakarta:Gramedia Pustaka Utama.

Buchori, Alma. 2007. Pemasaran Stratejik Jasa. Cetakan Pertama. Bandung: Alfabeta.

Fajar, Laksana. 2008. ManajemenPemasaran. Yogyakarta: Grahallmu.

Grant, John. 2007. The Green Marketing Manifesto. John Wiley \& Sons, Ltd., WestSussex, England.

Karna, Juslin. 2001. Green Advertising, Greenwash or a True Reflection of Marketing Strategies?.GMI 33, 61.

Kotler, Philip dan Keller. 2007. Manajemen Pemasaran. Edisi 12. Jilid 2. Jakarta: PT Indeks. 2009. Manajemen Pemasaran. Edisi 13. Jilid 1. Jakarta: Erlangga.

Kotler, $\begin{array}{cr}\text { Philip. } & 2009 . \\ \text { ManajemenPemasaran. Edisi }\end{array}$
13 jilid 2. Jakarta: Erlangga. Lupiyoadi, Rambat. 2001. ManajemenPemasaranJasa: TeoridanPraktek. Jakarta: SalembaEmpat.

Mathur, Lynette Knowles. 2000. An Analysis of the Wealth Effects of Green Marketing Strategies. Journal of Business Research, Vol. 50.

Moriarty, Sandra. 2011. Advertising. Edisidelapan. Jakarta: Kencana.

Mourad, Mahadan Yasser Ahmed. 2012. Perception of Green Brand in an Emerging Innovative Market. Emeraldinsight, 15:4.

Nanere, M. 2010, "What Green Marketing Has to Offer", International Conference Indonesian Management Scientist Ass (AIMI). La Trobe University, Bendigo, Australia.

Ottman, J.A. 1994. "Green Marketing: Challenges and Opportunities for the New Marketing Age", NTC Publishing Group, Lincolwood.

Oyewole, Philemon. 2001. Social Costs of Environmental Justice Associated withthe Practise of Green Marketing. Journal of Business Ethics, Vol. 29.

Ozkocak, L. L. 2011. A Content Analysis: Environment Themes and Tools in Newspapers Advertisements. Online Journal of Communication and Media Technologies, 1(3):2

Peter, J. Paul dan Jerry C. Olson. 2000. Consumer Behavior. 
Perilaku konsumen dan Strategi Pemasaran. Jilid 2.Edisi 4. Diterjemahkan oleh: DamosSihombing. Jakarta: Erlangga.

Pujari, Devashish, Gillian Wright, Ken Peattie. 2003. Green and competitive. Influenceson environmental new product development performance. Journal of Business Research, Vol. 56.

Rahim, M.H.A. 2012.Green Advertising and Environmentally Responsible Consumer Behavior.Asian Sosial Science, 8(5):47.

Schiffman, Leon dan Leslie L. Kanuk.2008.Perilaku

Konsumen. Edisi Ketujuh. Diterjemahkan oleh: Zoelkifli Kasip. Jakarta: Indeks.

Schiffman. Leon. danKanuk. Leslie Lazar. 2004. Consumer Behaviour 7 thEdition (PerilakuKonsumen). Jakarta: PT. Indeks.

Shimp, Terence A. 2000. Periklanan Promosi: Aspek Tambahan Komunikasi Pemasaran
Terpadu. Edisi 5 jilid 2 . Jakarta: Erlangga.

Singarimbun, Masri. 1995. Metodologi Penelitian Survei. Jakarta: Ghalia Indonesia.

Singgih Santoso dan Fandy Tjiptono. 2000. Riset Pemasaran Konsep dan Aplikasi dengan SPSS. Jakarta: PT. Gramedia.

Situmorang, James R. 2011. Jurnal Administrasi Bisnis, Vol.7, No.2: hal. 131-142, (ISSN:0216-1249) Center for Business Studies. FISIP Unpar.

Sugiyono. 2006. Metode Penelitian Bisnis. Cetakan Ketujuh .Bandung: Alfabeta CV.

Suharsimi, Arikunto. 2006. Prosedur Penelitian. Edisi Revisi Keempat. Jakarta: Penerbit Cipta.

Widayat dan Amirullah. 2002. Riset Bisnis. Edisi 1. Malang: CV. CahayaPress.

Widayat. 2004. Metodologi Penelitian Pemasaran: Aplikasi Software SPSS. Malang: UMM Press 